\title{
SIMBOL UNTUK MENUNJANG SISTEM INFORMASI DESAIN KEMASAN MAKANAN DAN MINUMAN PLASTIK
}

\author{
Devi Kurniawati Homan \\ Jurusan Desain Komunikasi Visual, Fakultas Komunikasi dan Multimedia, \\ Bina Nusantara University, Jl. K.H. Syahdan No. 9, Kemanggisan, Palmerah, Jakarta Barat \\ devikurniawatihoman@yahoo.com
}

\begin{abstract}
The use of plastic as packaging food and beverages has increased along with the development of technological and cultural changes in society. But this change has not been followed by an adequate understanding of the various types of plastic and usefulness. Symbols and information system on packaging become important information for consumer and visual communication designer. Based on field research, literature research and desktop research, the author summarizes that the information in the form of significant symbols are important to be put on the design of plastic packaging for food or beverage. During this time, several foods and beverages in plastic packaging have included the plastic code. But generally consumers do not have enough knowledge about these codes. This is where the role of visual communication designers becomes an important. Symbols and information systems which prepared in well design will be more easily to understand. With easily understandable symbol and information systems, consumer certainly would be wiser to choose and avoid the negative impact during the bad use of food and beverage plastics packaging.
\end{abstract}

Keywords: symbol, system, information, package, plastic

\begin{abstract}
ABSTRAK
Penggunaan plastik sebagai kemasan makanan dan minuman semakin meningkat seiring dengan berkembangnya teknologi dan perubahan budaya di masyarakat. Namun perubahan ini belum diikuti oleh pengetahuan yang memadai mengenai berbagai jenis plastik dan masing-masing kegunaannya. Simbol dan sistem informasi pada kemasan menjadi salah satu elemen yang penting diketahui oleh masyarakat umumnya dan desainer komunikasi visual khususnya. Berdasarkan riset lapangan, riset literatur dan riset melelui internet, penulis berhasil merangkum informasi berupa simbol-simbol penting yang penting untuk diketahui dan diperhatikan pada kemasan makanan atau minuman plastik yang akan digunakan. Selama ini beberapa kemasan makanan dan minuman plastik telah mencantumkan kode plastik yang digunakan. Namun pada umumnya masyarakat belum memiliki cukup pengetahuan tentang kode-kode tersebut. Disinilah peranan desainer komunikasi visual menjadi penting dan besar. Simbol dan sistem informasi yang didesain dengan baik akan lebih mudah dimengerti dan dicerna oleh masyarakat. Dengan simbol dan sistem informasi yang mudah dimengerti tentunya masyarakat pun akan lebih mudah teredukasi agar terhindar dari dampak negatif akibat kurangnya pengetahuan akan plastik dan penggunaannya.
\end{abstract}

Kata kunci: simbol, sistem, informasi, kemasan, plastic 


\section{PENDAHULUAN}

Desain kemasan berkembang seiring dengan perkembangan teknologi dan perubahan budaya di masyarakat. Hal ini mengakibatkan semakin tingginya kebutuhan akan informasi, proteksi, dan distribusi pada kemasan. Pengunaan plastik sedemikian meluasnya bahkan karena sangat tinggi tingkat ketergantungan padanya sehingga hampir-hampir sudah tak dapat terpisahkan dari kehidupan keseharian kita, tak terkecuali untuk kemasan makanan.

Apabila Anda pergi ke supermarket atau ke toko bahan kebutuhan sehari-hari, maka akan sangat mudah dilihat bahwa kemasan makanan dan minuman yang dijual rata-rata menggunakan bahan plastik. Bahkan apabila Anda membeli jajanan di pinggir jalan pun, sang penjual menggunakan kemasan plastik sebagai pembungkus makanan yang dibawa pulang. Tidak heran karena plastik merupakan bahan pembungkus makanan yang murah harganya, mudah didapat dan tahan lama. Tetapi di balik itu, banyak masyarakat yang tidak mengetahui bahaya dari plastik itu sendiri, apabila kita tidak benar menggunakannya. Seperti contohnya pada penjual gorengan di pinggir jalan ataupun penjual bakso keliling. Apabila pembeli menginginkan untuk membawa pulang makanannya, dan sang penjual tidak memiliki kemasan untuk dibawa pulang, biasanya mereka menggunakan plastik keresek untuk mengemas makanan tersebut. Atau misalnya kita membeli minuman air mineral kemasan botol, dan kita tetap menggunakannya dengan mengisi ulang dengan teh panas atupun kopi panas. Yang sebenarnya harus diketahui oleh masyarakat dan desainer adalah informasi mengenai penggunaan plastik tersebut apakah berbahaya bagi kesehatan dan apakah akibat yang mungkin terjadi apabila terjadi penggunaan yang salah pada plastik tersebut. Oleh sebab itu desain kemasan menjadi ujung tombak untuk mengkomunikasikan pesan secara visual pada target pasarnya.

Teori Forgiveness pada Universal Priciples of Design (Lidwell, Holden \& Butler, 2003) di mana desain membantu masyarakat untuk menghindari dan meminimalisasi konsekuensi negatif yang mungkin terjadi, menjadi landasan dan tujuan penulisan ini. Pengetahuan akan sistem informasi pada kemasan makanan dan minuman plastik menjadi kebutuhan yang sangat penting untuk diketahui oleh masyarakat umumnya dan desainer komunikasi visual khususnya.

\section{METODE PENELITIAN}

Penelitian untuk sistem informasi kemasan makanan dan minuman dalam kaitannya dengan desain komunikasi visual ini, berdasarkan studi lapangan, studi literatur dan riset melalui internet. Pertama-tama penulis melakukan riset lapangan terlebih dahulu, mengumpulkan contoh-contoh kemasan makanan dan minuman plastik yang beredar di masyarakat. Kemudian mengumpulkan apa sajakah informasi penting yang harus ada pada kemasan makanan dan minuman plastik. Dilanjutkan dengan studi literatur dan riset melalui internet mengenai kemasan dan informasi apa sajakah yang biasanya harus dicantumkan pada kemasan makanan

\section{HASIL DAN PEMBAHASAN}

Desain kemasan makanan dan minuman berfungsi untuk melindungi produk makanan atau minuman berdasarkan sifat dari produk itu sendiri. Sebagai contohnya, kemasan untuk susu, tentunya berbeda dengan kemasan untuk air mineral. Karena susu memiliki umur yang terbatas dan harus terlindung dengan baik, supaya produk dapat dikonsumsi tanpa rusak atau basi. Lain halnya dengan air mineral yang memiliki umur lebih panjang dan membutuhkan kemasan yang tahan terhadap udara atau air, karena apabila tidak terlindung dengan baik, akan mempengaruhi kemurnian air mineral tersebut. 
Pada dasarnya kemasan makanan dan minuman plastik tidak bisa dilepaskan dari kebutuhan rasa aman dan sehat. Karena makanan dan minuman secara langsung berdampak pada kesehatan masyarakat yang mengkonsumsi makanan dan minuman dari kemasan tersebut. Berdasarkan riset dari penulis, ada beberapa informasi yang sangat perlu dicantumkan pada desain kemasan untuk mempermudah masyarakat dalam penggunaan kemasan plastik untuk makanan dan minuman. Dengan adanya informasi pada desain kemasan, masyarakat pun dapat mengetahui bagaimana memperlakukan limbah plastik bekas kemasan makanan atau minuman yang mereka konsumsi. Bahkan berhati-hati dengan beberapa jenis kemasan makanan atau minuman plastik yang tidak aman untuk digunakan berulang-ulang.

\section{Sistem Kode Daur Ulang pada Material Botol Plastik}

Ada tujuh logo daur ulang bernomor untuk membedakan jenis plastik dan masing-masing kegunaannya. Kode-kode ini diperkenalkan pada tahun 1988 oleh by the Society of the Plastics Industry (SPI). Logo-logo tersebut berupa tiga buah panah melengkung dua dimensi, yang cocok digunakan pada plastik yang dibentuk menjadi kemasan makanan atau minuman.

Tabel 1 Kode Resin

\begin{tabular}{|c|c|c|c|c|c|}
\hline $\begin{array}{c}\text { Nomor } \\
\text { Daur Ulang }\end{array}$ & Simbol & $\begin{array}{c}\text { Simbol yang juga } \\
\text { digunakan }\end{array}$ & Singkatan & Nama Polymer & Kegunaan \\
\hline 1 & & & $\begin{array}{l}\text { PETE atau } \\
\text { PET }\end{array}$ & $\begin{array}{l}\text { Polyethylene } \\
\text { terephthalate }\end{array}$ & $\begin{array}{l}\text { PET transparan, jernih, kuat, dan memiliki } \\
\text { sistem perlindungan yang baik terhadap } \\
\text { air, udara dan kelembaban. } \\
\text { Plastik nomor daur ulang satu ini biasanya } \\
\text { dipergunakan sebagai botol minuman dan } \\
\text { kemasan plastik. Botol-botol ini hanya } \\
\text { direkomendasikan untuk sekali pakai. } \\
\text { Botol ini selain tidak boleh dipakai } \\
\text { berulang-ulang juga tidak boleh dipakai } \\
\text { untuk air hangat / panas atau air yg } \\
\text { didiamkan di sinar matahari langsung, } \\
\text { karena dapat mengakibatkan lapisan } \\
\text { polimer pada botol tersebut meleleh dan } \\
\text { apabila terminum dapat memicu penyakit } \\
\text { kanker. Itulah sebabnya mengapa rasa air } \\
\text { di dalam botol yang disinari matahari } \\
\text { langsung menjadi tidak enak, ini sangat } \\
\text { membahayakan kesehatan. } \\
\text { Contoh plastik nomor daur ulang satu } \\
\text { adalah botol air mineral, botol jus, botol } \\
\text { softdrink, botol salad dressing, selai } \\
\text { kacang, jeli, selai buah, acar. } \\
\text { Serpihan dan pelet PET yang telah } \\
\text { dibersihkan dan didaur ulang dapat } \\
\text { digunakan untuk membuat serat benang } \\
\text { karpet, fiberfill, dan geotextile. }\end{array}$ \\
\hline 2 & & HDPE & HDPE & $\begin{array}{l}\text { High-density } \\
\text { polyethylene }\end{array}$ & $\begin{array}{l}\text { HDPE dapat digunakan untuk membuat } \\
\text { berbagai macam tipe botol. Botol-botol } \\
\text { yang tidak diberi pigmen bersifat tembus } \\
\text { cahaya, kaku, dan cocok untuk mengemas } \\
\text { produk yang memiliki umur pendek } \\
\text { seperti susu. Karena HDPE memiliki } \\
\text { ketahan kimiawi yang bagus, plastik tipe } \\
\text { ini dapat digunakan untuk mengemas } \\
\text { deterjen dan bleach. Hasil daur ulangnya } \\
\text { dapat digunakan sebagai kemasan produk } \\
\text { non-pangan seperti shampo, kondisioner, } \\
\text { pipa, ember, dll. }\end{array}$ \\
\hline
\end{tabular}


(3) $\hat{3}$

4
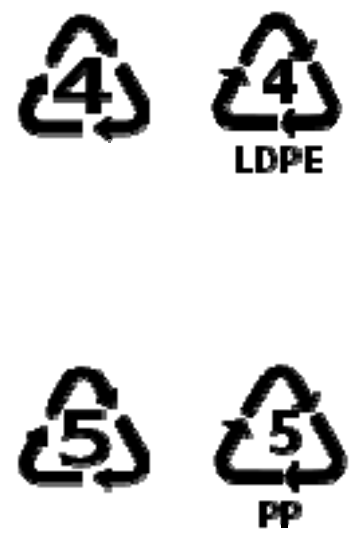

6

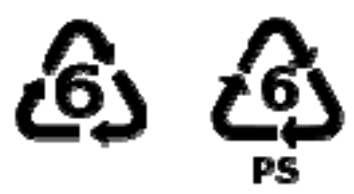

7

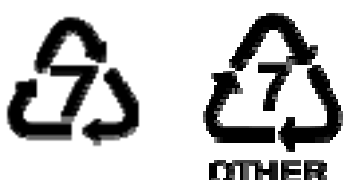

\section{PVC atau V}

PVC atau

chloride

LDPE

Low density

polyethylene

PP

Polypropylene

PS

Polystyrene

OTHER atau

$\mathrm{O}$
Plastik lainnya, termasuk acrylic, acrylonitrile butadiene styrene, fiberglass, nylon,

polycarbonate, dan polylactic
Plastik nomor daur ulang tiga ini memiliki karakter fisik yang stabil dan tahan terhadap bahan kimia, pengaruh cuaca, aliran, dan sifat elektrik. Bahan ini paling sulit untuk didaur ulang dan biasa digunakan untuk pipa dan kontruksi bangunan. Kandungan dari PVC yaitu DEHA pada plastik pembungkus dapat melumer ke makanan bila dipanaskan. Zat ini sangat berbahaya bagi ginjal dan hati.

Plastik nomor daur ulang empat ini memiliki massa jenis rendah dengan tekstur yang lembek dan lentur. Biasa dipakai pada barang-barang yang memerlukan fleksibilitas. Plastik ini hampir tidak dapat dihancurkan. Namun tetap baik untuk tempat makanan. Contoh plastik nomor daur ulang empat adalah squeezable bottles (pada botol mustard, madu).

Plastik dengan nomor daur ulang lima ini merupakan memiliki daya tahan yang baik terhadap bahan kimia, kuat, dan meiliki titik leleh yang tinggi sehingga cocok untuk produk yang berhubungan dengan makanan dan minuman seperti tempat menyimpan makanan, botol minum, tempat obat dan botol minum untuk bayi. Plastik ini dapat kita isi ulang. Biasanya didaur ulang menjadi casing baterai, sapu, sikat, dll.

Plastik dengan nomor daur ulang enam ini biasa dipakai sebagai bahan tempat makan styrofoam, tempat minum sekali pakai, tempat $C D$, karton tempat telor, dll. Pemakaian bahan ini sangat dihindari untuk mengemas makanan, karena bahan styrine dapat masuk ke dalam makanan ketika makanan tersebut bersentuhan. Bahan Styrine berbahaya untuk otak dan sistem syaraf manusia. Banyak negara bagian di Amerika sudah melarang pemakaian tempat makanan berbahan styrofoam termasuk negara China.

Plastik dengan nomor daur ulang tujuh ini terbuat dari resin yang tidak termasuk enam golongan yang lainnya, atau terbuat dari lebih dari satu jenis resin dan digunakan dalam kombinasi multi-layer. Contoh plastik kode tujuh lainnya adalah Computer cases, iPod, galon air, kacamata plastik, benang nilon, alat elektronik. 


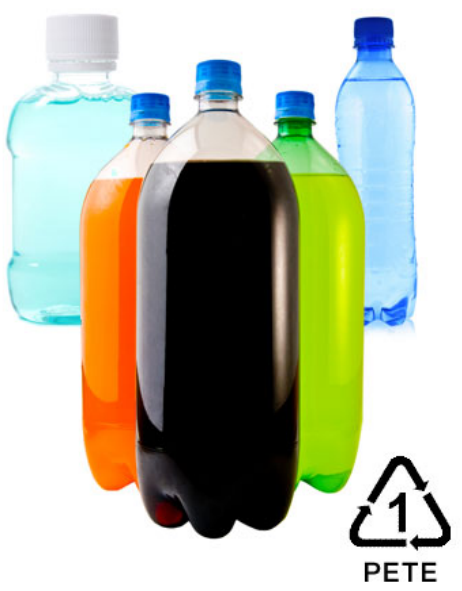

Gambar 1 Contoh kemasan plastik PETE

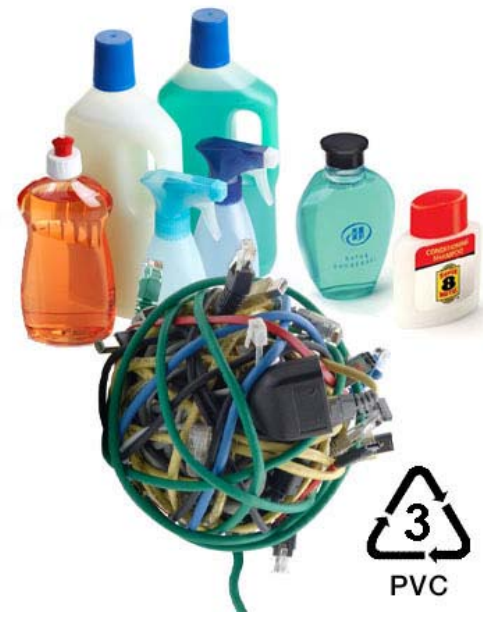

Gambar 3 Contoh kemasan plastik PVC

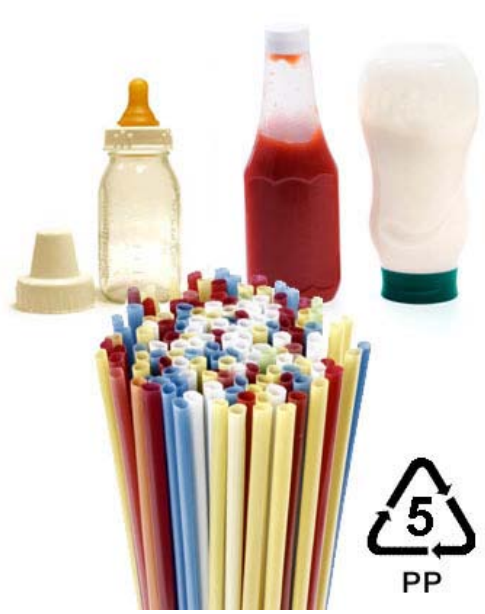

Gambar 5 Contoh kemasan plastik PP

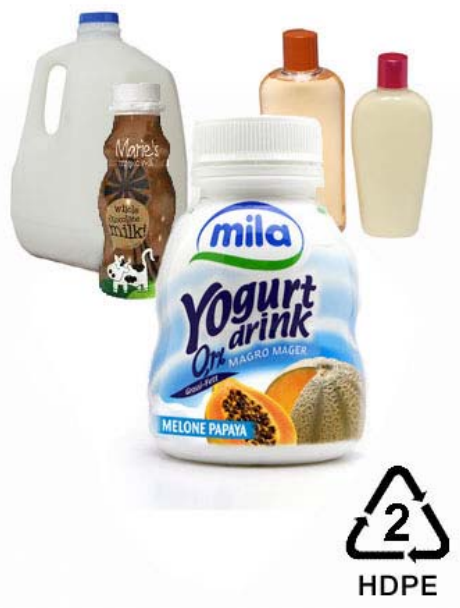

Gambar 2 Contoh kemasan plastik HDPE

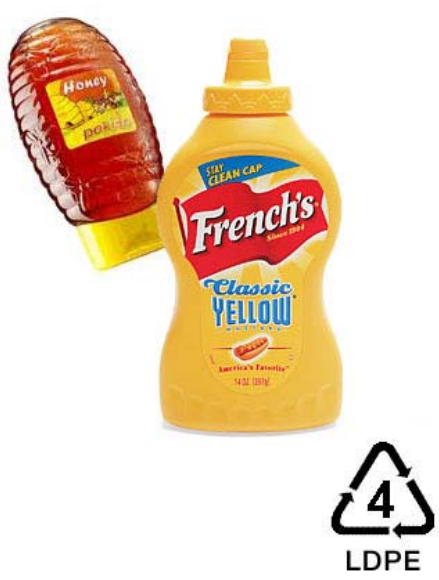

Gambar 4 Contoh kemasan plastik LDPE

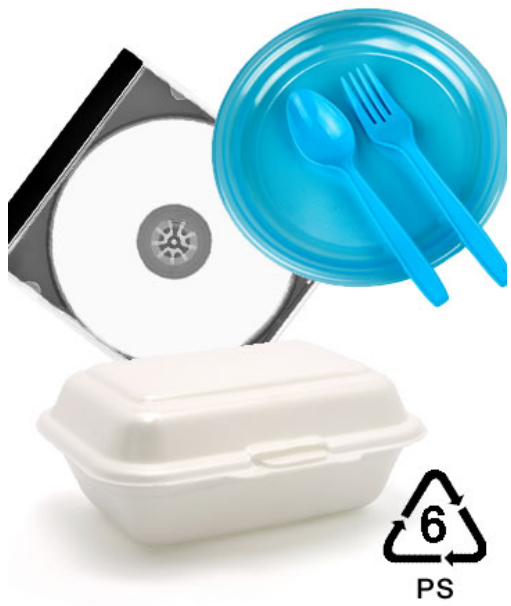

Gambar 6 Contoh kemasan plastik PS 


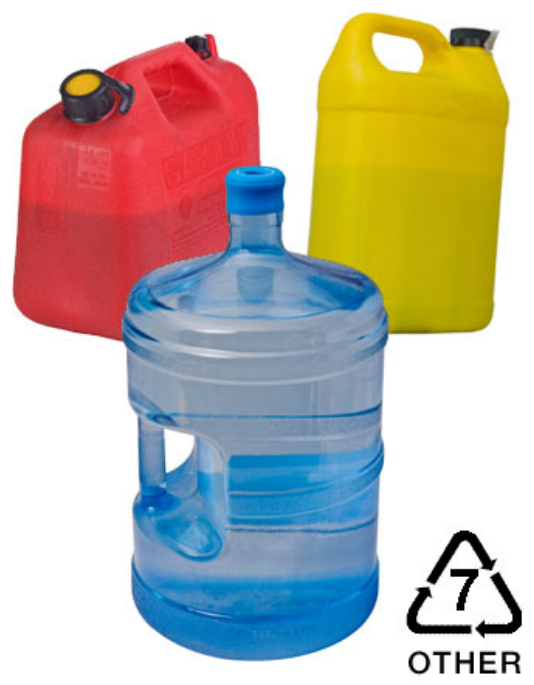

Gambar 7 Contoh kemasan plastik OTHER

Bagi masyarakat awam cara mudah untuk menghindari bahaya plastik, yaitu dengan membedakan antara plastik untuk kemasan makanan dan untuk keperluan lainnya. Karena karakteristik peruntukannya, maka bahan baku dan proses pembuatannya pun berbeda. Plastik untuk kemasan bahan makanan seharusnya dibuat berdasarkan Standar Nasional Indonesia (SNI) sehingga lebih aman pada suhu tertentu dan lemak/minyak.

Pada plastik untuk kegunaan lainnya, misalnya plastik keresek, hindari pemakainnya dari makanan berminyak dan suhu panas, karena zat-zat adiktif dalam plastik mudah terurai dalam lemak dan panas, apabila terkontaminasi dengan makanan yang masuk ke dalam tubuh, secara akumulaitf pada binatang percobaan dapat mengakitbatkan penyakit kanker, perubahan hormon dan menyebabkan kelahiran berjenis kelamin ganda.

Hal ini tentu, dikhawatirkan dapat berdampak buruk juga bagi kesehatan manusia. Karena tidak semua produk kemasan plastik tercantum SNI, maka lebih baik tidak memasukkan makanan panas dan belemak/berminyak ke dalamnya. Lalu bagaimana dengan botol susu untuk balita? Setelah botol direbus, dinginkan. Buatlah adukan susu panas di gelas kaca, setelah hangat, baru masukkan ke botol. Selain itu, banyaknya plastik dengan jenis melamin untuk wadah makanan yang dijual di pasar dengan bentuk dan motif menarik serta harga murah membuat masyarakat tertarik untuk membeli tanpa memperhatikan keaslian produk. Cara yang paling mudah untuk mengetahui keasliannya yaitu dengan merebus plastik tempat wadah makanan dalam air panas selama satu jam, apabila terjadi perubahan bentuk atau pecah, maka dapat diindikasikan melamin tersebut palsu. Melamin palsu terbuat dari bahan yang berbahaya seperti, formalin, urea dan bahan berbahaya lainnya.

Selain itu, untuk menyelamatkan lingkungan dari bahaya plastik, saat ini telah dikembangkan plastik biodegradable, artinya plastik ini dapat diuraikan kembali oleh mikroorganisme secara alami. Plastik yang demikian, terbuat dari material yang dapat diperbaharui, yaitu dari senyawa-senyawa yang terdapat dalam pati tanaman misalnya tapioka, jagung. Namun penggunaan plastik ini mengalami kendala yaitu harga yang jauh lebih mahal dari plastik biasanya. Di Indonesia belum diterapkan standar penggunaan plastik, masih sebatas himbauan. Berbeda dengan negara maju lainnya misalnya Jepang, telah diterapkan standar penggunaan plastik dan sanksi terhadap pelanggaran penggunaan plastik. 


\section{PENUTUP}

Berdasarkan hasil riset penulis, dapat disimpulkan bahwa penggunaan plastik haruslah sesuai dengan peruntukan masing-masing plastik tersebut. Penggunaan yang salah dapat berakibat buruk. Bahkan penggunaan yang salah secara berkepanjangan dapat berakibat pada cacad fisik dan kematian. Desainer komunikasi visual penting untuk mengetahui dan mencantumkan informasi penting tersebut pada kemasan / label makanan dan minuman yang mereka desain. Masyarakat pun dapat berhati-hati, mengetahui peruntukan plastik tersebut, dan menghindari penggunaan yang salah. Untuk kedepannya, penulis berharap adanya kampanye untuk menyebar luaskan pentingnya informasi ini. Sehingga masyarakat Indonesia menjadi lebih hati-hati dalam pemilihan dan penggunaan kemasan plastik untuk makanan dan minuman.

\section{DAFTAR PUSTAKA}

Lidwell, W., Holden, K., \& Butler, J. (2003). Universal principles of design. Massachusetts: Rockport Publishers.

\section{RIWAYAT PENULIS}

Devi Kurniawati Homan lahir di kota Tasikmalaya pada 08 September 1982. Penulis menamatkan pendidikan S1 di Universitas Bina Nusantara dalam bidang desain komunikasi visual pada tahun 2004. Saat ini bekerja sebagai desainer di Mendiola Design Associates sejak tahun 2004. Penulis aktif mengajar di Universitas Bina Nusantara pada jurusan desain komunikasi visual sejak tahun 2005. 